\title{
O tempo e a psiquiatria: os 70 anos da APRS
}

\author{
Time and psychiatry: 70 years of APRS
}

\author{
Flávio Shansis, Paulo Oscar Teitelbaum* \\ * Editores, Rev Psiquiatr RS.
}

"A vida é uns deveres que nós trouxemos para fazer em casa.

Quando se vê, já são 6 horas: há tempo...

Quando se vê, já é 6 ${ }^{\mathrm{a}}$ feira...

Quando se vê, passaram 60 anos...

Agora, é tarde demais para ser reprovado...

E se me dessem - um dia - uma outra oportunidade, eu nem olhava o relógio.

Seguia sempre, sempre em frente...

E iria jogando pelo caminho a casca dourada e inútil das horas."*

A questão do tempo preenche a mente do homem desde que a ele foi dada a faculdade de pensar. De pensar e de se pensar. E, de imediato, a noção do tempo the trouxe uma outra: a da mortalidade. A psiquiatria, ao se ocupar do homem, se ocupa também do tempo.

Neste número de nossa revista, decidimos propositadamente abordar esse tema. Não por acaso ele já se faz presente na capa desta edição, com a obra da artista plástica gaúcha Laura Castilhos denominada "Tempo". Decidimos por esse assunto ao pensarmos a nossa prática clínica e nossa vida associativa.

Na prática psiquiátrica, o tempo se dá a perceber sob múltiplas expressões. De um ponto de vista clínico, o tempo já era percebido por pioneiros da medicina ao valorizarem a necessidade da observação do desenvolvimento de sinais e sintomas que, ao final, se expressavam em uma síndrome $\mathrm{e}$, mais adiante, em uma doença.

$\mathrm{Na}$ psiquiatria clínica, trabalhos fundamentais de estudiosos como Emil Kraepelin descreveram a importância da observação longitudinal de pacientes, de seus temperamentos pré-mórbidos, de seus pródromos de doença e, ao final, da consolidação de um quadro mórbido completo. Essa noção do tempo necessário para se chegar à conclusão mais precisa sobre um paciente permanece hoje em dia ainda de forma primordial - apesar de toda a pressão que os atuais manuais diagnósticos exercem ao valorizarem um diagnóstico transversal, como uma foto de um instante que, muitas vezes, pouco nos diz sobre a evolução de um transtorno.

\footnotetext{
* Mario Quintana, Esconderijos do tempo, Porto Alegre, L\&PM, 1980.
}

Na prática psicanalítica, o tempo é o caminho pelo qual a dupla terapêutica se movimenta, buscando chegar ao conhecimento, à compreensão e, assim, oferecer ao paciente a possibilidade de atingir melhores "lugares psíquicos" onde viver, através das elaborações possíveis dos conflitos estabelecidos no passado, porém atualizados e ativos no presente.

Na vida associativa, também o tempo nos surpreende. Quando percebemos, já se passou quase um século, e isso é muito, especialmente em um país tão jovem como o nosso, aqui no já chamado "novo mundo". A instituição da qual a nossa revista é o órgão oficial, a Associação de Psiquiatria do Rio Grande do Sul (APRS), comemora 70 anos de existência. É, já, uma respeitável senhora, tem sua história e seu tempo. Anossa revista nasceu depois, quando a APRS já contava com seus 40 anos e, madura, sentiu a necessidade de criar um canal de desenvolvimento e difusão do conhecimento psiquiátrico por ela produzido.

Esta data é um marco para todos nós, sócios da APRS. Sentimo-nos também amadurecendo e, talvez por isso, mais capacitados a entender o tempo e sua imperiosa limitação. Ao longo de seus quase 30 anos de publicação ininterrupta, a Revista de Psiquiatria do Rio Grande do Sul acolheu a produção científica de inúmeros associados da nossa APRS, muitos dos quais já cumpriram seu ciclo vital e nos deixaram. Porém, suas idéias permanecem, sobrepujando a imperiosa limitação do tempo, mantidas vivas na história da nossa instituição, registradas nas páginas da revista. Assim é, por exemplo, com o Dr. Cyro Martins, cujo centenário de nascimento é lembrado em 2008 através da criação, pela APRS, de um prêmio que leva o seu nome, destinado a estimular a produção científica de jovens psiquiatras.

A Revista de Psiquiatria do Rio Grande do Sul celebra a longevidade da instituição à qual pertence $\mathrm{e}$ sente-se orgulhosa em ter contribuído ao longo dessa história como um canal de expressão de suas capacidades científicas.

Enfatizar o tempo nesta edição - em nossa capa e no presente editorial - é a forma pela qual decidimos homenagear os 70 anos da APRS e seus sócios: profissionais que se ocupam de seres humanos e de como o tempo os aflige. 